Oct., Nov., Dec., 1951

\title{
Life IS For Living
}

\section{Elizabeth Cruickshark}

$\mathbf{T}$ IME we spend out of doors provides delight for the hours when dull routine tasks must be done.

We can re-live at will the joyous experience of finding dozens of young robins-when we thought they had all gone south-devouring the dried crab apples on a neighbor's tree.

Or the thrill on a wet cold day when the prairie was truly just "a lovely place against the sky" and suddenly a brightness was all about - Myrtle Warblers were in the road, the ditches, the trees; yellow rumps always evident as they flew hither and thither oblivious to the weather.

Or the interesting day of contrasts in late autumn, tracking the 'bird of happiness'. Following one bluebird into a valley ravine-hoping to discover a flock - we found a clump of purple violets, odd old tree stumps, a basketful of mushrooms, beautiful shelf fungi, chickadees everywhere and in the clearing, a company of longspurs rising and falling in waves, as if in fun, on a bed of Silverwood, now a glowing carmen carpet.

We love to remember, too, the last Sunday in October when we found so many misplaced signs of spring; Moss Fhlox in flower, clumps of Crocuses in inch-high fur coats, fresh green rosettes of Androsace, Early Loco Weed, one Blue Bell, Chickweed, Bladder-pod and Pussy Willow. How symbolic of Autumn, which someone has described as not so much a season of itself as a remembrance of all seasons!

Nor can we ever forget the day in early fall when unexpectedly the "soft and silent snow-white petals from the flowers that grow in the cold atmosphere" covered the ground, and Judy and I went to see Mr. Tom Mack's Museum at Lumsden. Ir the workshop, where his hand-made bee-hives were formerly fashioned with skill and pleasure, Mr. Mack has collected and preserved old. Indian antifacts, spear and arrowheads, stones and minerals found in the Valley.

Articles from near and far are arranged so that they may be handled easily. A large shallow loyalist maple ladle, hook-shaped handle, caught the eye. Was it used to skim the boiling syrup in the out-door kettles? Near it were old candle dips, ancient wrought iron sconces and cancile snuffers. Tiny Lancashire clogs reminded us of the child labour of Dicken's day. We examined bits of dinosaur skeleton, of lava, of Hadrian's wall; a starfish, a cocoarut-like case of brazil nuts, intricate ingenious predecessors of the jig-saw puzzle (one closed-a little block-open a set of doll's furnitule). Of all the things-too numerous to mention-of crowning interest were matching pieces of Diamond Willow, found near the river bank, which are to become a candelabra. With an artist's eye for beauty and colour Mr. Mack has chosen them, removed the bark revealing markings flowing like warm liquid honey, catching the light in their dull gold and amber sheen. A finished single candle stick on a base from the grooved trunk, and simply waxed, is a real collector's treasure item.

As we came down the hill, passing a bed of Johnny-jump-ups, their gay little faces only above the snow, we stopped to admire the view with Mrs. IMack from her window. Nestled on a shelf on the hillside, they are high enough to view the wide prairie skies above the far side of the Valley that was alive with burgundy, chartreuse and copper in shouting contrast to the soft white snow.

What privilege is theirs to be able to lift up their eyes unto the hills and to welcome the morning as it descends to the valley each new day.

A lone Pine Grosbeak was enjoying russet-red haws - two Redbreasted - Nuthatches flitted upside down on the tree tips as we came into Judy's yard. We had enjoyed our too short visit with the Macks, for to this contented couple-in Graysonian manner, life was for living.

"Birds are Nature's most
eloquent expression of Beauty,
Joy and Freedom."
-Dr. Frank M. Chapritan.

